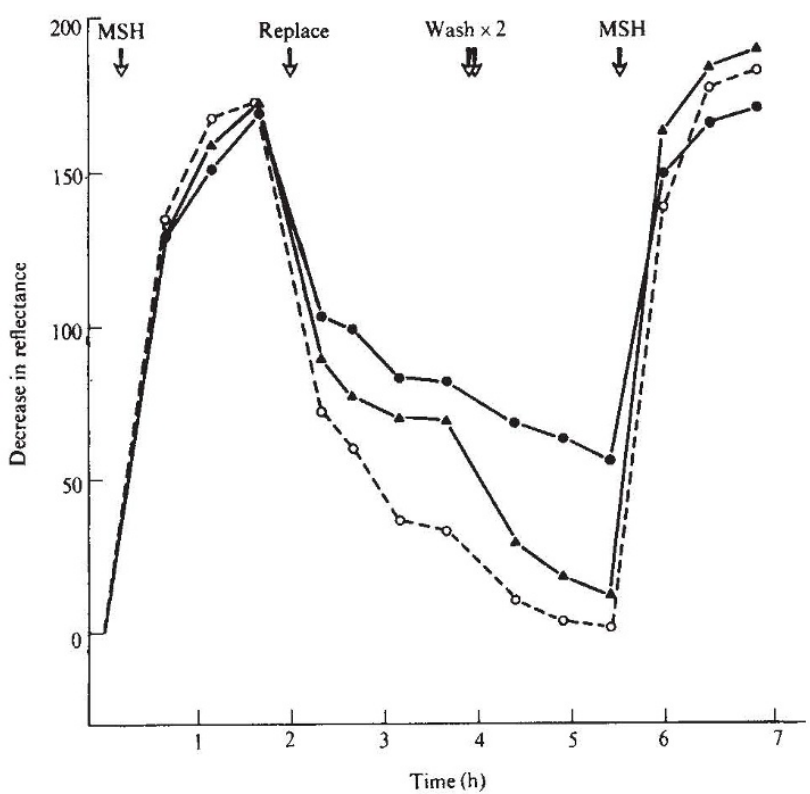

Fig. 2 The effect is seen of cytochalasin B on lightening of frog skin previously darkened by MSH. Specimens were incubated in Ringer solution with MSH (1.5 U/ml.), which was then replaced by Ringer solution with or without cytochalasin B. Later the specimens were washed twice, and still later they were again incubated with MSH. Cytochalasin B $(5 \mu \mathrm{g} / \mathrm{ml}$. $) ; A$, cytochalasin B $(0.5 \mu \mathrm{g} / \mathrm{ml}) ;$.0 , control.

effect on the aggregation of melanin granules previously dispersed by MSH.

The interference of cytochalasin B in darkening and lightening of frog skin suggests that a contractile microfilament system is involved in the movement of melanin granules in melanocytes. In frog epidermal melanocytes-which are much smaller than dermal melanocytes and do not contribute significantly to changes in reflectance-melanin granules dispersed by MSH and then treated with cytochalasin B $(20 \mu \mathrm{g} / \mathrm{ml}$.) tend to aggregate, with marked reduction in the number of microfilaments seen (J. McGuire and G. Moellmann, personal communication). In specimens treated with high concentrations of cytochalasin $\mathrm{B}$, the frequent failure of reflectance to return to base line is a secondary effect; such specimens, subsequently treated with MSH, darken like controls (Fig. 2).

A contractile system of microfilaments might provide the motive force for the movement of granules, particularly for their dispersion, while the integrity of microtubules seems also to be important for efficient aggregation. An investigation of the ultrastructure would be useful for further examination of these possibilities.

This work was supported by the US Public Health Service, the Arthritis Foundation, the John A. Hartford Foundation and by a research career development award of the National Institutes of Health. I am grateful to I.Irs G. V. Flynn and Mrs M. G. Breitenstein for technical assistance.

Stephen E. Malawista

Department of Internal Medicine,

Yale University School of Medicine,

New Haven, Connecticut

Received June 28, 1971.

1 Malawista, S. E., J. Exp. Med., 122, 361 (1965).

2 Malawista, S. E., J. Cell Biol, , 49, 848 (1971).

3 Borisy, G. G., and Taylor, E. W., J. Cell Biol., 34, 525 (1967).

4 Borisy, G. G., and Taylor, E. W., J. Cell Biol., 34, 535 (1967).

3 Shelanski, M. L., and Taylor, E. W., J. Cell Biol., 34, 549 (1967).

6 Wilson, L., and Friedkin, M., Biochemistry, 6, 3126 (1967).

7 Creasy, W. A., Pharmacologist, 9, 192 (1967).

8 Weisenberg, R. C., Borisy, G. G., and Taylor, E. W., Biochemistry, 7, 4466 (1968).

9 Bikle, D., Tilney, L. G., and Porter, K. R., Protoplasma, 61, 622 (1966).
10 Green, L., Proc. US Nat. Acad. Sci., 59, 1179 (1968).

11 Wikswo, M. A., and Novales, R. R., Biol. Bull. (Woods Hole), 137, 228 (1969).

12 Schroeder, T. E., Exp. Cell Res., 53, 272 (1968).

13 Schroeder, T. E., Biol. Bull., 137, 413 (1969).

14 Wessells, N. K., Spooner, B. S., Ash, J. F., Bradley, M. O., Luduena, M. A., Taylor, E. L., Wren, J. T., and Yamada, K. M., Science, 171, 135 (1971).

is Shizume, K., Lerner, A. B., and Fitzpatrick, T. B., Endocrinology, 54, 553 (1954).

16 Wright, M. R., and Lerner, A. B., Endocrinology, 66, 559 (1960).

\section{Muscarinic Action of Acetylcholine}

THE muscarinic excitatory action of acetylcholine on central and peripheral neurones has been suggested to involve a reduction in membrane conductance for potassium ions ${ }^{1,2}$. This proposal was supported by observations that 2,4-dinitrophenol (DNP) could specifically suppress the excitation by acetylcholine of cerebral cortical neurones in the cat without affecting the excitatory action of L-glutamate, and that the hyperpolarization of these neurones by DNP involved an increase in the membrane conductance for potassium ions ${ }^{3}$.

We report that the excitation of spinal Renshaw cells by a cholinomimetic which interacts with muscarinic receptors cannot be selectively reduced by DNP. The excitation of these cells by acetyl- $\beta$-methylcholine is very sensitive to atropine and is relatively insensitive to dihydro- $\beta$-erythroidine ${ }^{4}$, and hence may be assumed to result from an interaction with muscarinic receptors. Experiments were performed on Renshaw cells of the seventh lumbar segments of cats anaesthetized with chloralose $(60 \mathrm{mg} / \mathrm{kg}$, intraperitoneal). Extracellular action potentials were recorded with the $\mathrm{NaCl}$-containing central barrel of seven barrel micropipettes, and acetylcholine (bromide, $0.5 \mathrm{M}$ ), acetyl- $\beta$-methylcholine (bromide, $0.5 \mathrm{M}$ ), L-glutamate (Na salt, $\mathrm{M}, p \mathrm{H} 7.5$ ), DL-homocysteate ( $\mathrm{Na}$ salt, $0.2 \mathrm{M}, p \mathrm{H}$ 7.5) and DNP (Na salt, 0.1 M, pH 9) were administered with suitably directed electrophoretic currents from aqueous solutions in the other barrels.

It was an invariable finding (seven Renshaw cells, five cats) that concentrations of DNP (anionic currents of 40-60 nA) which reduced the sensitivity of Renshaw cells to acetyl- $\beta$ methylcholine had a quantitatively similar effect on the sensitivity to acetylcholine, L-glutamate and DL-homocysteate. Concentrations adequate to completely block the action of the cholinomimetics also abolished that of the excitant amino-acids and spontaneous firing: such effects were often associated with a reduction in the amplitude of extracellularly recorded action potentials and were fully reversible. Although these results would be consistent with a hyperpolarizing action of $\mathrm{DNP}^{3}$, which might reasonably be considered to diminish the apparent effectiveness of all excitants, the effect of DNP on Renshaw cells may be more closely related to processes involved in the generation of action potentials and hence also relatively nonselective towards excitants. Preliminary experiments indicate a similar, but not readily reversible, effect of iodoacetate.

Thus the effects of DNP on acetylcholine sensitive cortical neurones may not be directly applicable to the mechanisms of activation of muscarinic receptors on neurones elsewhere in the nervous system.

Department of Physiology,

Australian National University, Canberra

Received July 27, 1971.

${ }^{1}$ Godfraind, J. M., Krnjević, K., and Pumain, R., Nature, 208, 562 (1970).

${ }^{2}$ Krnjević, K., Pumain, R., and Renaud, L., J. Physiol., 215, 247 (1971).

${ }^{3}$ Godfraind, J. M., Kawamura, H., Krnjević, K., and Pumain, R., J. Physiol., 215, 199 (1971).

4 Curtis, D. R., and Ryall, R. W., Exp. Brain Res., 2, 66 (1966). 